\title{
YELLOW FEVER AND THE CONSTANT NEED FOR EPIDEMIOLOGICAL SURVEILLANCE
}

\section{ORIGINAL ARTICLE}

GITIRANA, José Valdeci Almeida ${ }^{1}$

GITIRANA, José Valdeci Almeida. Yellow Fever and the constant need for epidemiological surveillance. Revista Científica Multidisciplinar Núcleo do Conhecimento. 04 year, Ed. 11, Vol. 06, pp. 05-15. November 2019. ISSN: 2448-0959, Access link in: https://www.nucleodoconhecimento.com.br/health/yellow-fever

\section{SUMMARY}

Objective: to unveil the factors that justify the importance of efficient epidemiological surveillance for the control of yellow fever in the country. Method: exploratory, bibliographic, qualitative and descriptive research. Results: the latest epidemiological surveys indicate that the number of cases of wild yellow fever recorded in Brazil is very variable, thus, if it is considered that for each detectable case there are 10 other cases of subclinical evolution, the actual figures may be much larger than those recorded by health agencies. Conclusion: Yellow fever, as an acute infectious disease, is a difficultto-control zoonosis, as it is capable of causing unpredictable epidemics in human populations, an example is the moment experienced by the State of Minas Gerais, which suffers from an outbreak of disease, motivated by conditions of environmental imbalance that favor the development and proliferation of vectors, cooperating for the occurrence of hundreds of deaths in the first months of 2017 alone.

Keywords: control, yellow fever, diagnosis, epidemiological surveillance.

${ }^{1}$ Specialist in Clinical Analysis, Graduated in Pharmacy, Currently medical academic. 


\section{INTRODUCTION}

Yellow fever is an acute infectious disease, which is a serious public health problem in most tropical countries, where environmental conditions favor the development and proliferation of vectors, causing dozens of cases of deaths Annually. It may present in mild or subclinical forms and even severe forms characterized by the triad consisting of jaundice, hemorrhages and acute renal failure, with a mortality rate, in severe cases, between 20 and $50 \% .{ }^{24}$

The etiological agent of this disease is an RNA arbovirus belonging to the Family Flaviviridae. This virus remains in nature in a wild cycle, having primates as reservoir and mosquitoes of the genus Hemagogos as vectors, and another urban, in which the reservoir is man himself and has the mosquito Aedes aegypti as a vector, in this specific case the disease is transmitted from sick man to unimmunized man through vector sting. ${ }^{25}$

Clinically, the incubation period is usually three to six days. However, longer periods have already been described. The clinical spectrum of the disease ranges from a benign condition, characterized by nonspecific febrile disease, to a fulminant disease characterized by multiple organ dysfunction, in particular hemorrhages ${ }^{1}$. Thus, the patient may undergo an asymptomatic period, with subsequent fever, headache, generalized muscle pain, photophobia, chills, jaundice, and may evolve with bleeding conditions and acute renal failure ${ }^{2,3}$.

Yellow fever is a disease of compulsory notification and all suspected cases should be confirmed laboratoryally. Diagnosis should be substantiated through epidemiological data, clinical manifestations described for the various forms, and laboratory data. However, a more accurate diagnosis is obtained through serological research of specific antibodies and histopathological and immunohistochemical analysis of liver specimens ${ }^{4}$. From the pathogenetic point of view, lesions can be observed in the liver, kidneys, heart, spleen and lymph nodes 1 , however, the most important lesion of this disease occurs in the liver at the level of hepatocytes. 
The yellow fever causing virus is taxonomically classified family Flaviviridae, genus Flavivirus. Flavivirus is spherical, envelopated, and measure about 40-50 nm. Its genome (RNA) consists of a single, linear, non-segmented tape, presenting sedimentation coefficient of 44S, containing approximately 10,0862 nucleotides, molecular weight of $4 \times 106 \mathrm{kd}$, Have 10 genes, which will encode 10 proteins: three proteins C, M, E; and seven non-structural proteins, NS1, NS2a, NS2b, NS3, NS4a, NS4b and NS5 5 .

Protein $C$ can be in viral capsid. Proteins $M$ and $E$ are constituents of the viral envelope. Protein $\mathrm{E}$ is glycosylated and has important antigenic determinants, main responsible for inducing the immune response and also has considerable value for the binding of the virus with the host membrane receptor. Protein $\mathrm{M}$ (not glycosylated) is the result of the cleavage of pre-M protein (glycosilated) 1.

However, there are studies that have also stressed the importance of NS1 and NS3 proteins in the host's immune response. The first has the ability to activate complement and induce the lysis of infected cells, while NS3 is one of the main targets of cytotoxic T lymphocyte attack ${ }^{6}$.

After penetration of viral particles into the cytoplasm and denudement, RNA replicates in perinuclear regions, mediated by an RNA of negative polarity. The maturation of the visrions occurs in intracellular membranes, with the virus sprouting from the Golgi apparatus or the endoplasmic reticulum, and two distinct types of viral particles can be defined: the viruses associated with cells and particles extracellular virals. ${ }^{26}$

Viruses belonging to the Flaviviridae family have the ability to replicate in both mosquitoes and primates, including man. They have great adaptability, which implies saying that this characteristic has a direct relationship in the maintenance of these viruses in nature. ${ }^{27}$

From an eminently epidemiological criterion, one can define the yellow fever virus as an arbovirus whose primary cycle primarily involves forest mosquitoes and non-human primate species, especially Callitrichidae and Cebidae, among neotropical primates, 
most species in South America when infected, in general, present fatal evolution, a fact not observed in African species. Similarly, species such as birds, rodents, marsupials, carnivores, amphibians and reptiles are generally resistant to yellow fever virus ${ }^{7}$.

Mosquitoes involved as vectors of yellow fever are anthropophilic of daytime activity in treetops, in the wild environment and therefore human infection is accidental and consequent to human penetration in the place where zoonosis occurs. In the urban environment it is necessary the presence of vectors living in the home or peridomicile of urban man 1.

Several vector species of this pathology have been studied over the years and may vary according to the region investigated, among them we can mention: Haemagogos janthimomys, Haemagogus albomaculatus and leucocelaenus, Hg. janthinomys, Sabethes chloropterus and Sabethes soperi, Aedes abopictus and Aedes aegypti, among others. ${ }^{28}$

From the point of view of transmission man plays an important role in spreading the virus to areas where it does not occur naturally, but which have vectors and monkeys, which are part of the disease transmission cycle. In addition, changes in the forest, usually caused by the opening of roads, logging and agriculture activity, accidentally expose unimmunized individuals to wild invertebrate vectors, being one of the main forms of transmission of disease in the Brazilian Amazon ${ }^{3,4}$.

It is worth remembering that, even if not prevalent in our country, another form of maintenance of the virus in nature can occur in urban areas, with Aedes aegypti being the vector involved and man the only host. The urban form of yellow fever was eradicated from Brazil in 1942. However studies have shown the presence of Aedes aegypti in about 21 Brazilian states ${ }^{7}$.

Therefore, a viremic patient from an endemic area of wild yellow fever may, associated with the high densities of Aedes aegypti, constitute a potential stimulus for the 
reurbanization of yellow fever, which would have serious consequences especially for the previously immunized population ${ }^{7.4}$.

Studies have raised the hypothesis of possible participation of Aedes albopictus in the transmission cycle of the disease, whose ability to transmit the virus has already been demonstrated in the laborator ${ }^{11,8,9}$. Because this agent can breed in rural, peri-urban and urban environments, it can potentially serve as a bridge between the wild and urban cycle of yellow fever. In Africa, several species of the genus Aedes, such as Aedes furcifer, Aedes taylori and Aedes luteocephalus, are as important urban vectors as Aedes aegypti ${ }^{5}$.

The response to amarílica infection is broad and variable, in this perspective, it is estimated that about $90 \%$ of cases with clinical expression are of the forms classified as mild and oligosymptomatic, that is, presenting few symptoms and that only $10 \%$ are of the forms Serious. In addition, there are people who develop asymptomatic conditions 8 .

Such asymptomatic forms, as well as subclinical cases and mild forms of the disease are often noticeable in low-age children whose mothers were vaccinated and transmitted maternal $\lg G 9$ antibodies to the ${ }^{\mathrm{m}}$. On the other hand, there are individuals who develop more severe forms of the disease, such as people who have never been vaccinated and, therefore, are completely helpless to the disease. These individuals, in turn, develop severe and extremely severe clinical conditions of the disease.

It is noteworthy that in mild and moderate forms of the disease symptomatology is undifferentiated and not characteristic, that is, it is confused with many common diseases in endemic areas, such as malaria, viral hepatitis, typhoid fever, among another ${ }^{10}$.

In general, symptoms in mild form are restricted to headache and asthery, accompanied by febrilcula or moderate fever. It evolves for up to two days, after the end of these the patient recomposes without showing sequelae. In its moderate form, the patient besides being able to present these symptoms may even be accompanied 
by nausea with absence of vomiting, in addition to myalgias and arthralgias that do not even bother the patient or prevent his locomotion.

Headache usually lasts longer. Fever only ends with the use of antithermal sandthey already more persistent. At least one of the classic indications of the disease is accompanied from this symptomatic picture: jaundice or oliguria/anuria and hematonesis (black vomiting) 8 . The duration of such a state is two to three days and recovery is integral. The picture evolves into two periods, with a remission phase between them. It should be emphasized, however, that it is not always possible to separate such phases. ${ }^{8}$

The symptomatology of the classical form of yellow fever is severe and characterized by an abrupt onset, after an average incubation period of 6 days (period ranging from infecting bite to the onset of symptom manifestation) and which can last about two weeks. At first there is high fever, in which the patient reports having felt well and completed his occupations a few hours before 8 . Fever is unaccompanied by increased pulse ${ }^{11}$.

Conversely, it is common to observe high fever with pulsation drop, such a sign is known as faget sign ${ }^{12}$. Shortly after the onset of fever, holocranial headache of such intensity is manifested that the patient often feels the need to request the use of analgesics ${ }^{13}$.

These situation accompany diffused muscle pain, especially in the back, where they are usually present. Asthesia, prostration and nausea conclude this picture that evolves from 2 to 3 days and matches the prodromic period 8 .

In several patients, evolving to the infectious period, there is a phase of improvement that is characterized by a feeling of relief and immediate cure on the part of the patient, because low fever or else ceases, muscle pain decreases and headache passes to a state Bearable.

This period lasts from 12 to 48 hours and, after that, unlike individuals who develop the mild and moderate forms that actually cure, the status of these patients suddenly 
worsens, with the worsening of all symptoms previously presented, together with the emergence of 11 othe ${ }^{r s}$. This signal is the beginning of the period of intoxication, toxemic or "localization phase", because in this period the virus becomes circular in the blood to be located only in the liver. In it nausea intensifies and vomiting arise abruptly. These symptoms onset are eating and then widely hemorrhagic ${ }^{12}$.

Vomiting is coffee smudge color if blood has suffered reaction from gastric juice, or widely hemorrhagic if bleeding is recent or intense. It is evidenced that other hemorrhagic manifestations are commonly found. The most present hemorrhages are of tegumentary tissue, gums and ear ${ }^{14}$. In the gastrointestinal tract, melena may occur, when stomach hemorrhage is wide or when it presents the manifestation of bowel bleeding ${ }^{15}$.

Accompanying or even preceding bleeding, there is the presence of thrombopenia, often so intense that it can reach less than $20,000 / \mathrm{mm} 3$ of blood. It is interesting to show that some patients, even with such platelet levels, do not bleed. While others with rates between 50,000 and 100,000 platelets manifest exorbitant bleeding. It is noticed that the degree of intensity of hemorrhage is not always interconnected with platelet count ${ }^{14}$.

Among these symptoms, jaundice, the existence of yellowish color on the skin and sclerotic eyes 14 appears $^{\text {rs }}$ Jaundice is, in short, of the verdainian type and is due to the fact of the increase in the direct fraction 8. Around the 5th to 7th day of the state period, renal failure is installed, which initially presents due to decreased urinary volume and, if untreated rapidly can trigger anuria and complete stop of diuresis due to acute tubular necrosis widespread that is installed. This is the time when deaths 11,12 are most often occuring.

Those who survive recover slowly, but totally and without sequelae. During convalescence, indisposition, astheria and muscle painusually extend for up to two weeks. 
It is worth noting that in Africa the occurrence of fulminant forms are often reported, which are characterized with an evolution of up to three days, resulting from renal failure and, almost always, without the presence of jaundice or even liver alterations 16.

At the other extreme, rare cases of late death due to yellow fever may be highlighted, cases that are associated with late heart injuries ${ }^{17}$. Finally, it cannot be stressed that in cases where jaundice is abrupt and serum bilirubin levels are very high encephalopathy is frequent, being a sign of poor prognosis. However, most patients progress to death either by hepatorenal insufficiency or due to bleeding, which are often uncontrollable.

Specific examination for the definitive diagnosis of yellow fever is the isolation of the virus, also called culture examination. Through this examination it is possible to detect viral antigens and viral RNA 9. In addition, it is possible to diagnose the disease through the use of serological methods, such as the dosage of specific antibodies by the ELISA MAC method by capturing IgM in an enzymatic assay or serological conversion in inhibition tests of the hemaglutination $(\mathrm{IH})^{18}$.

In this perspective, the isolation of the virus can be done by combining different systems, such as in the case of virus isolation, this will only be possible after inoculation of the suspicious sample, when evidence of viral replication is obtained around the 5th to 7 th $^{\circ}$ day of culture. Thus, when separated, the viral sample can be identified in indirect immunofluorescence tests, using monoclonal antibodies or alternatively by complement fixation tests ${ }^{16}$.

On the other hand, serological methods that indicate specific $\operatorname{lgM}$, as with the case of Mac ELISA, can give an agile presumptive diagnosis with a serological sample, if it is collected from the patient from the 5 th day of disease ${ }^{19}$. Thus, the manifestation of IgM may be the result of recent (2-3 months) or current (current) infection, for this reason the importance of having the complete epidemiological and clinical history for the interpretation of the laboratory result. It is important to highlight that antiamarílica 
vaccination can foster the formation of $\lg \mathrm{M}$ and, therefore, it is extremely important to know the patient's vaccination history.

As there is not yet a specific and effective drug for the treatment of this disease, tests that diagnose as positive for infection take around a week. Supportive treatment should be started immediately, and the patient's hospitalization with severe forms in hospitals with good infrastructure preparation for any disease and preferably in the ICU is emphatic, since there is a need for a number of procedures that are only deliberating more easily in these units ${ }^{12}$.

However, drug treatment should only be focused to combat symptoms, thus the medication to be prescribed depends on the clinical manifestations of the patient, but it is customary to use antithermal and analgesics at the commonly indicated doses, ranging from according to factors such as age and weight.

It is worth highlighting the contraindication of the use of medicines that have acetylsalicylic acid or their derivatives in their formula, since it may aggravate bleeding phenomena that may be associated with the evolution of the disease ${ }^{8,1} 1$.

With vomiting, controlling medications such as metoclopramide are common. In addition, it is recommended the use of medicines to preserve the gastric mucosa, called $\mathrm{H} 2$ blockers, such as cimetidine and ranitidine, with these as an example, which are extremely useful to prevent gastric bleeding. These bleeding can be consolidated as one of the most fatal complications of yellow fever. When renal failure is evidenced through oliguria it is important that diuretic drugs should be prescribed ${ }^{19}$.

It cannot be emphasized that the patient's evaluation should be constant and includes actions such as the investigation of vital signs, diuresis, and the request for at least the following tests: blood count, platelets, urine summary and verification of liver functions ( dosage of aminotransferases, bilirubin and GT range) and renal (urea and creatinine dosage, and monitoring of water balance) ${ }^{19}$. Thus, given the conditions in which patients have renal failure installed and does not respond to common diuretics it is 
important to indicate hemodialysis or peritoneal dialysis, depending on the patient's evolution and considering worsening of the condition.

\section{METHOD}

Yellow fever has been in the past as a great martyrdom for the Brazilian population and even today, despite the existence of the antiamarílica valin, it is cause for concern. Above all, due to the severity it can reach and may even evolve to death. It is an acute infectious disease, which is a serious public health problem in many tropical countries, where environmental conditions favor the development and reproduction of vectors. Its etiological agent is an RNA arbovirus belonging to the Family Flaviviridae. 4 In this work, a comprehensive view is launched on the various ways of coping with this great public health problem and on the importance of its control through an efficient yellow fever surveillance system.

Thus, this research was carried out qualitatively 22 since it addresses yellow fever, emphasizing the need for constant epidemiological surveillance. In this perspective, this article is presented in descriptive form, based on the theoretical regard used in the research, reporting the main characteristics of the pathology, which firm the need for surveillance in the country through actions that emphasize prevention.

\section{RESULTS}

Yellow fever is a disease of mandatory notification and, as such, any case with suspicion should be immediately communicated to the local, state or national health authority, which in turn has a duty to report the case to international bodies ${ }^{20}$.

If confirmed or disposed of, the notification of the case is passed to the national authority, which in turn confirms or discards the subpoena to the international health authority. This should always be done to expedite preventive measures and prevent possible outbreaks ${ }^{21}$.

It is important to emphasize that the most efficient method to prevent the occurrence of yellow fever is still vaccination with the 17D sample. From this perspective, it is 
cautioned that all healthy people more than six months of age, who are exposed or exposed to possible contamination by infection $8,10,16$, are properly vac ${ }^{\text {cinated }}$.

A single dose of the vaccine protects the individual for at least 10 years, during which time revaccination is recommended. However, it is worth emphasizing that some studies have shown that people vaccinated only once and living away from risk areas indicate neutralizing antibodies for up to 35 years, which denotes the reliability and efficacy of the vaccine ${ }^{1} 6$.

Considering the fact that the vaccine is produced with the live virus attenuated, it is not advisable that people with immunodeficiency at the risk of virulence reversal in a host with immune system depression be vaccinated ${ }^{29}$.

Patients with cancer, AIDS/AIDS and using medication that decreases the immune response of the body should not be vaccinated, except in cases specifically predetermined by the medical authority ${ }^{8}$.

Therefore, in addition to vaccination, combating vectors and the use of individual protection are forms of prevention of yellow fever, but it should not be lost in view that the fight against forestry vectors is basically unfeasible, so that the fight against the urban vector becomes relatively easy ${ }^{2} 9$.

\section{DISCUSSION}

Considering the recent outbreak of wild yellow fever that plagues the rural area of the State of Minas Gerais and spreads throughout the country it is undeniable to emphasize that it is the duty of the coordination of the Yellow Fever Surveillance and Control Program (PVCFA) to find solutions for improve and sophisticated the surveillance of the disease in the national territory, among the actions that encompass this duty are: to define risk areas, to enable laboratories to have the means to identify cases of the disease, promote health education actions in order to to raise awareness about the need for prevention, among others. However, some measures ${ }^{23}$ should be 
endowed in order to make epidemiological surveillance in Brazil in relation to yellow fever more effective, such as:

- Adopt a more open case definition than that advised by the Pan American Health Organization (PAHO), preferably introducing a syndromic approach, with the purpose of increasing the receptibility and usefulness of the system ${ }^{20}$;

- Improve the qualification of information to increase the convenience of the system in analyzing and detecting historical trends ${ }^{2} 0$;

- Evolve the surveillance system of epizootics and entomological as primordial axes of early detection of viral circulation in Brazil, especially in areas where the resident population is not yet vaccinated ${ }^{2} 0$;

- Integrate knowledge, new techniques and technologies to achieve the premises of the program, such as the use of geographic information to detect possible trends in viral distribution and dispersion and verify correlation with environmental data, entomological and demographic, emphasizing developing a model capable of calculating risk areas for yellow fever ${ }^{20}$.

It is worth noting that, although the last manifestation of urban yellow fever has been documented more than 60 (sixty) years ago in the country, the possibility of reemergence cannot be disregarded. Especially when potentially favorable factors can be easily identified ${ }^{14}$.

One of these factors is precisely the dispersion of Aedes aegypti in thousands of municipalities, which is the need for new possibilities for public health. Especially sanitary order ${ }^{23}$.

Moreover, one cannot fail to emphasize the fact that the maintenance of the proliferation of wild yellow fever is an intention to the health of the population. Mainly due to the epidemic capacity it can assume in urban populations that have rates lower than $50 \%$ of vaccination coverage ${ }^{223}$. 
In short, the combination of these ideas indicates that yellow fever surveillance should work side by side with the surveillance of human cases, surveillance of epizootics in non-human primates and entological surveillance, with a view to increasing efficacy for more cleared of viral circulation ${ }^{2} 3$.

Why any case suspected of yellow fever should be transmitted immediately to the appropriate organs and, after notification, an immediate investigation should be carried out which should not exceed the maximum period of up to 24 hours after the subpoena, the result should be disclosed within 60 days.

From this perspective, epidemiological surveillance actions are actions in the face of suspected human cases:

- Detect as many cases with suspicion as possible (symptomatic and asymptomatic) and notify them to increase the assessment of the population at risk;

- To find cases of epizootics in the territory in order to identify the risk area;

- Guide actions to control the epidemic (vaccination and combat the urban vector);

- Highlight the results.

As mentioned, the disease integrates a wide range of differential diagnoses with diseases such as malaria, hepatitis, leptospirosis and other ichthysis and/or hemorrhagic diseases, which uncloses in a high percentage of cases not considered by the records of surveillance systems.

In view of this, the PVCFA recommends the syndromic approach in surveillance through the use of a single calculation and maintenance form through laboratory tests, as means to determine the opportunity and increase the efficacy, scientific adherence and characterization of the national epidemiological surveillance system, aiming to postulate the methodical and constant wakefulness of ichthyic and/or hemorrhagic febrile syndrome in sentinel service units, prioritizing the expanded and recent measurement of suspected $\operatorname{cases}^{2} 3$. 
Entomological surveillance is also a way to combat the disease, especially through the seizure of wild vectors in places where epizootics and/or human cases occur.

In addition, the strengthening of laboratory capacity is essential, especially when it is considered that the principle of this subcomponent is to improve laboratory efficacy for the early identification of yellow fever virus in primates that do not human beings and human beings themselves also ${ }^{24}$.

With this, the foundation for diagnosis is required with a focus on virus research in potential vectors, added to the construction of data for the detection of culicidal species confined in research areas. It is noteworthy that, nowadays, the laboratory network is coming from central laboratories (LACENs), with emphasis on the Adolfo Lutz Institute, as distinguished regional and the Evandro Chagas Institute as the national reference laboratory ${ }^{3} 0$.

Health education is a point to mention, especially when it is considered that this is an important mechanism and that it should occupy a central position in epidemiological surveillance actions, since it is a need for the population to understand in fact the disease to be to change its conduct towards prevention $9,10,20,21$.

Finally, one cannot fail to mention the conceptions for the surveillance of yellow fever in Brazil. In this perspective, it has been that one of the functions of epidemiological surveillance is to monitor the health status of populations to assist public policies in order to provide safe and healthy places 15 , in view of this, it seeks to realize the monitoring yellow fever of a creative bias, in order to reach all the numerous spaces of outbreaks of proliferation of the disease, which, once detected and mapped, will become intervention territories ${ }^{13}$.

Therefore, actions in this sense should be directed to better clarify ecological and environmental risk factors that articulate the circulation of the virus.

Thus, obtaining data from the implementation of new tools and new perspectives should offer the additional precise information so that viable action guidelines can be postulated, which are based on firm and precise bases of analysis and interpretation, 
so that they can generate new recommendations of prevention and control measures that will actually contribute to the improvement of surveillance, prevention and control of yellow fever in the country ${ }^{20}$.

Initiatives such as these support the production of knowledge for the improvement of the management and operationalization of the epidemiological surveillance system. Thus, one should increase the understanding of the process of dissemination of the yellow fever virus, taking into account the factors that promote the risk of exposure, mechanisms of assimilation and early perception of viral diffusion from primates and vectors, and also schemes that can categorize and differentiate the threat between predisposed and vulnerable areas. Especially where civilians are not vaccinated ${ }^{15}$.

However, there are still severe difficulties in municipalities to ensure the full advance of a notorious and effective PVCFA, including insufficient capital funds, laboratory training problems in the face of the necessary demands and vigil actions epidemiological use of resources because of poor management by local politicians. In addition to the financial resources always scarce for the health sector ${ }^{17}$.

Therefore, it is expected that the tools already in force can support the expansion and training of the framework of health professionals who are willing to accept the challenges of operationalization and restructuring of epidemiological surveillance of yellow fever in the supporting tools for better performance of its function as an instrument of change, intervention and health incentive.

\section{CONCLUSION}

With the urbanization of rural centres, the possibility of emergence of certain diseases, such as yellow fever, is growing, which would have serious consequences for public health, especially in regions where the vaccination coverage rate is low.

The modification of the environment caused by logging activity, opening roads, agriculture, among others, accidentally expose unimmunized individuals to wild invertebrate vectors, being one of the main forms of transmission of the mazela in the 
Brazilian Amazon. This fact was constituted over the years as a relevant justification for the numerous cases of mortality that occurred in the states of the Legal Amazon. Until the beginning of 2017, in Brazil, episodic cases occurred in states located outside this area were identified. However, the first months of 2017 revealed the need to intensify surveillance, given that the expansion of the outbreak involves other states besides Minas Gerais, such as Goiás, São Paulo and Mato Grosso, in addition to the Amazonian States. This need is explained by the fact that a virulent patient from an endemic area of wild yellow fever may, associated with the high densities of Aedes aegypti, constitute potential stimulus for reurbanization of the disease in Brazil. This statement is reinforced by current studies, which indicate the presence of Aedes aegypti in about 21 Brazilian states 7 , which reinforces the need for surveillance.

From this perspective, the need for an efficient PVCFA arises, so that it can, in fact, exercise control over the possible foci of the disease and, in addition, achieve through education in the health discipline and training of professionals to maintain the risk of epidemic away from the urban population.

\section{REFERENCES}

1. VERONESI, R - Tratado de infectologia. São Paulo: Editora Atheneu, 1996.

2. COSTA, GZA; ROMANO, APM; ELKHOURY, ANM; FLANNRY, B - Evolução histórica da vigilância epidemiológica e do controle da febre amarela no Brasil. In: Rev Pan-Amaz Saude. 2011. Disponível em: http://scielo.iec.pa.gov.br/scielo.php?pid=S2176$62232011000100002 \&$ script=sci_arttext\&tlng=en. Acessado em: 01 dez. 2016.

3. MONATH, T.P - Yellow fever: an update. In: Lancet v.1, 2001, p.11-20.

4. QUARESMA, JAS - Apoptose e citocinas mediadoras da lesão hepática na febre amarela: subsídios para o redirecionamento dos mecanismos de lesão e suas consequências. 2003. 245-256f. Tese (Doutorado em Patologia Clínica) Faculdade de Medicina, Universidade de São Paulo, São Paulo, 2003.

5. LEÃO, RNQ - Doenças Infecciosas e parasitárias: enfoque amazônico. Belém: CEJUP, 1997. 
6. GALLE, RP; HOFMANN, WJ; WALCZAK, H; SCHALLER, H; OTTO, GSW; KRAMMER, PH.; RUNKEL, L - Envolvement of the CD95 (APO-1/Fas) receptor and ligand in liver damage. In: J. Exp. Med. v.182, p.1223-1230, 1998.

7. MASSAD, E; COUTINHO, FAB; BURATTINI, MN; LOPES, LF - The risk of yellow fever in a dengue-infested area. In: Trans. R. Soc. Trop. Med. Hyg. v.95, 2001, p.570-574.

8. FRANCO, O - A história da febre amarela no Brasil. Rio de Janeiro: Ministério da Saúde; 2009.

9. LACERDA, A - Em busca de um tempo perdido: fontes visuais para a história da vacina contra a febre amarela. In: BENCHIMOL, J - Febre amarela: a doença e a vacina, uma história inacabada. Rio de Janeiro: FIOCRUZ; 2010.

10.PORTO, M - Marcos técnicos e legais para a descentralização do controle de endemias. Brasília: Ministério da Saúde, 2014.

11. BENCHIMOL, J - Febre amarela: a doença e a vacina, uma história inacabada. Rio de Janeiro: FIOCRUZ, 2010.

12. BRANCO, J - Vigilância da febre amarela no Brasil. Rio de Janeiro: Fundação Oswaldo Cruz, 2008.

13. CALHEIROS, L - A febre amarela no Brasil. Rio de Janeiro: Fundação Oswaldo Cruz, 2008.

14. COSTA, GZA - Estudo das características epidemiológicas da febre amarela no Brasil, nas áreas fora da Amazônia Legal, período de 1999-2003 [dissertação]. Belém: Universidade Federal do Pará, 2005.

15. RIBAS, E - O mosquito como agente de propagação da febre amarela. Porto Alegre: Artmed, 2009.

16. SILVA, LM - Descentralização do controle de endemias. Brasília: Ministério da Saúde, 2011.

17. FARIA, GS - Endemias Rurais: métodos de trabalho adotados pelo DNERu. Rio de Janeiro: Ministério da Saúde, 2006.

18. HOMMA, A; CUNHA, J - Febre Amarela e Dengue. Rio de Janeiro: Fundação Oswaldo Cruz. 2007.

19. CAUSEY, C - Implantação dos estudos sobre arbovírus na região amazônica. 13 ed. Belém: Fundação Serviços de Saúde Pública, 2005. 
20.BRASIL. Ministério da Saúde - Guia de vigilância epidemiológica. 15 ed. Brasília: Fundação Nacional de Saúde, 2012.

21.BRASIL. Ministério da Saúde - Plano de Intensificação das Ações de Prevenção e Controle da Febre Amarela no Brasil. Brasília: Ministério da Saúde, 2008.

22. DEMO, P - Metodologia do conhecimento científico. 5 ed. São Paulo: Atlas, 2009.

23. COSTA, GZA; ROMANO, APM; ELKHOURY, ANM; FLANNRY, B - Evolução histórica da vigilância epidemiológica e do controle da febre amarela no Brasil. In: Rev Pan-Amaz Saude. 2011. Disponível em: http://scielo.iec.pa.gov.br/scielo.php?pid=S217662232011000100002\&script=sci_arttext\&tlng=en. Acessado em: 29 nov. 2016.

24. LIMA-CAMARA, T.N. Arboviroses emergentes e novos desafios para a saúde pública no Brasil. In: Rev. Saúde Pública. Disponível em: http://www.scielo.br/scielo.php?pid=S0034-

$89102016000100602 \&$ script=sci_arttext\&tlng=pt. Acessado em: 25 out. 2019.

25.lOPES, N; NOZAWA, C; LINHARES, R.E.C. Características gerais e epidemiologia dos arbovírus emergentes no Brasil. In: Revista Pan-Amazônica de Saúde. Disponível em: http://scielo.iec.gov.br/scielo.php?script=sci_arttext\&pid=S217662232014000300007. Acessado em: 25 out. 2019.

26.CAMPOS, F.S. Replicação Viral. 2018. Disponível em: http://www.ufrgs.br/labvir/material/replicacao_med.pdfAcessado em: 25 out. 2019.

27.BRASIL. Centro de Vigilância Epidemiológica. Sobre a Febre Amarela. 2018. Disponível em: http://www.saude.sp.gov.br/resources/cve-centro-de-vigilanciaepidemiologica/areas-de-vigilancia/doencas-de-transmissao-por-vetores-ezoonoses/famarela.html. Acessado em: 25 out. 2019.

28. GOMES, A.C; et al. Ecologia de Haemagogus e Sabethes (Diptera: Culicidae) em áreas epizoóticas do vírus da febre amarela, Rio Grande do Sul, Brasil. In: Epidemiologia e Serviços de Saúde. 2010. Disponível em: 
http://scielo.iec.gov.br/scielo.php?script=sci_arttext\&pid=S1679-

49742010000200003. Acessado em: 25 out. 2019.

29. SUCCI, R.C.M; FARHAT, C.K. Vacinação em situações especiais. In: Jornal de Pediatria. 2006.

Disponível

em:

http://www.scielo.br/scielo.php?script=sci_arttext\&pid=S0021

75572006000400011. Acessado em: 25 out. 2019.

30.CAMPOS, A.C.T; MATTOS, S.V.M. Avaliação de requisitos referentes à implantação do sistema de gestão da qualidade nos Laboratórios Centrais de Saúde Pública. In: Revista do Instituto Adolfo Lutz. 2009. Disponível em: http://periodicos.ses.sp.bvs.br/scielo.php?script=sci_arttext\&pid=S007398552009000300019\&lng=pt\&nrm=iso. Acessado em: 25 out. 2019.

Submitted: August, 2019.

Approved: November, 2019. 